\title{
DOES HUMAN CAPITAL PREDICT RESOURCES: EVIDENCE FROM DENOMINATIONAL INSTITUTIONS IN GHANA?
}

\author{
Anowuo, Isaac $\mathrm{PhD}^{1}$, Pastor Emmanuel Cobbina $\mathrm{PhD}^{2}$ \\ ${ }^{1,2}$ College of Business, Adventist University of the Philippines, Philippines
}

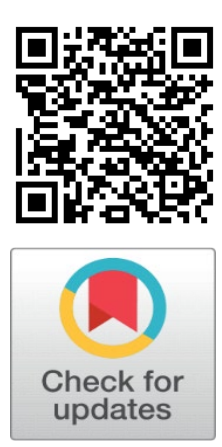

Received 3 August 2021

Accepted 17 August 2021

Published 31 August 2021

\section{CorrespondingAuthor}

Anowuo, Isaac PhD, isaacanowuo41@gmail.com

DOI

10.29121/granthaalayah.v9.i8.2021. 4171

Funding: This research received no specific grant from any funding agency in the public, commercial, or not-for-profit sectors.

Copyright: (C) 2021 The Author(s). This is an open access article distributed under the terms of the Creative Commons Attribution License, which permits unrestricted use, distribution, and reproduction in any medium, provided the original author and source are credited.

\section{ABSTRACT}

Life processes cannot continue in the absence of a means of survival. This explains why people continue to look for ways to make a living and satisfy their insatiable desires This study aims to investigate the relationship between human capital and financial resources in selected denominational institution in Ghana. This research is applied a questionnaire to measure and assess the mentioned relationship. The sample size is 368 persons who were chosen through purposive sampling technique. A Minitab 20.3 software was used to generate the required results. According to findings of empirical analysis, it is demonstrated that there is a significant and positive relationship between human capital and resources. The results also revealed that human capital elements of education, training and succession planning were predictors of resources. It recommended that human capital must be improved for better management of denominational resources.

Keywords: Human Capital, Resources, Denominational Institution

\section{INTRODUCTION}

Life processes cannot continue in the absence of a means of survival. This explains why people continue to look for ways to make a living and satisfy their insatiable desires. These means are collectively referred to as resources. The sources from which businesses obtain the funds they require to finance their investments, capital, and current operations are the resources. For any activity to take place, it requires the use of resources, just that the type of resource may vary depending on the type of activity being carried out Van Raaij (2016). Nonetheless, the economic problem of scarcity postulates that even though resources have various uses, they are limited in nature Van Raaij (2016). Therefore, regular use of resources may reduce their availability and quantity in supply. However, irrespective of the problems of scarcity, life processes must go on. So human beings must find a way to manage available resources to address human wants that are unlimited and insatiable. The only way to achieve this is by using resources effectively and efficiently (Cleaver, 2017). Thus, resources need to be well managed to ensure a continuous and regular supply or availability.

Nevertheless, this is not achieved on a silver platter. The concept of resource management started during the beginning of the agricultural revolution as soon as human beings realised the importance of resources and the idea of scarcity. The growing interest in resource management has become heightened in recent 
times due to the rapidly growing population. Population and resource use are related so that a growing population implies increasing human needs and increasing demand for resources. Those resources are scarce due to the high rate of depletion and low replacement rate (Herath \& Prato, 2017). Therefore, there is no option than to manage the available resource to sustain life. Resources management occurs in all aspects of life and the various sectors of all economies, being it households (individuals), the firm, organisations or the government, because there is increasing awareness that resource management ensures sustainability (Metz et al., 2016).

It is indisputable that every organisation and institution in the world relies heavily on the availability of resources to function effectively. Hence, resources need to be well managed (Rees, 2017). In Africa, resource mismanagement is even worse, and it happens in almost every institution. According to (Murithi, 2017) resource mismanagement is widespread in Africa, and it is the main reason Africa is lagged in terms of growth and development. Rahaman and Samkin (2017) find that Africa's problems have less to do with the scarcity of resources but more to do with resource mismanagement. It was argued further that it has led to the collapse of many vital institutions and has increased poverty and inequality among citizens. In the case of Ghana, mismanagement of economic resources is no news at all because it is always discussed on every media platform; the radio, television, newspapers and even on social media. According to Ghana's vice president, Dr Bawumia, Ghana's problem is not lack of resources but mismanagement of resources (Starfmonline, 2016). Just as mismanagement is standard in every aspect of Ghanaian society, the church is not exempted. Rockson (2019) claims that financial fraud in church organisations is increasing rapidly, affecting the reputation, donation appeal, future funding, and ability of church organisations to meet their planned organisational goals. Akotia (2019) identified a high level of resource mismanagement in Ghanaian churches and made recommendations on how it should be dealt with. This study seeks to address the problem of managing the resources of church organisations with human capital as tools for achieving organisational development.

People are valuable because they are believed to increase productivity and profitability. It follows then that companies that put more money into training their employees are more likely to be more productive and profitable. A business is only as good as its people, according to a common adage. A company's success depends on its ability to attract and retain top talent, which includes directors, employees, and managers Wright and Ulrich (2017). Investing in human capital acknowledges that not all labor is equal.

On the other hand, employers can improve the quality of that capital by investing in employees' education, experience, and abilities, all of which have economic value for employers and the economy as a whole. Thus, there are two types of human capital: general and specific Barro (2001). The term general skills refer to knowledge and skills applicable to various employers, including government agencies, accounting, marketing and personnel management expertise are examples. Individual employers may only be interested in certain types of skills, which are called specific skills. For instance, a company may have proprietary equipment that can only be operated by people who have received specific instruction in its use. People with that kind of training are only of interest to the Company if they can be hired.

The human capital theory was developed by Gary Becker when he described the economic approach to human behaviour Teixeira \& Tavares-Lehmann (2014). Lectures in labour economics establish that human beings possess marketable skills in the form of capital in which workers make a variety of investments. This idea, borrowed from the principles of human capital theory, helps understand investment 
incentives and the structure of wages and earnings. Therefore, human capital corresponds to any stock of knowledge or characteristics the worker has (either innate or acquired) that contributes to productivity Kyenzi et al. (2020). Human capital is described from a different point of view. It is therefore essential to discuss the various views that different individuals have classified.

Human capital, according to Hyenzi et al. (2020), plays a direct role in the production process. A worker's productivity is increased by human capital in all tasks, even if it varies in different tasks, organizations, and situations. It's possible to think of human capital as being represented (representable) by a unidimensional object, such as the stock of knowledge or skills. Indirectly, this stock contributes to the production process Estrin Mickiewicz and Stephan (2016).

Human capital, according to the Schultz/Nelson-Phelps view, is primarily defined as the ability to adapt. When dealing with "disequilibrium" or, more generally, with situations in which there is a changing environment and workers must adapt to it, human capital becomes crucial Ciccone \& Papaioannou (2009). "Human capital," according to the Bowles-Gintis school of thought, is the ability to work in an organizational setting, obey orders, and generally adapt to life in a hierarchical/capitalist society. For some, the primary purpose of education is to teach students the "correct" ideology and approach to life Gray (2019).

Human capital can be measured, but it is more a signal of ability than it is a set of independent characteristics that can be used in the production process Gray (2019). All three views agree that "human capital" will be valued in the market because it increases firms' profits, despite their differences.

There are differences between the Becker and Schultz views, but there are also similarities in the Gardener view. Workplace economists' view of human capital is actually a combination of these three approaches in many applications. The implications of the Bowles-Gintis view are very similar as well. As a result, firms will pay higher wages to educated employees because they will be more beneficial to the company because they will obey orders better and be more reliable members of the firm's hierarchy However, observable measures of human capital may be valued because they provide information about other characteristics of workers, according to Spence.

Resources are now in the hands of governments or powerful corporations, and how these resources are managed affects all humans and the physical environment. Geography, Economics, Biology and Ecology, Computer Science, Management and Human Resources have all applied the concept of resources. Competition, sustainability, conservation, and stewardship are all related to it Chan et al. (2020). Commercial or non-commercial factors in human society require resource allocation through resource management.

The process by which businesses effectively manage their various resources (tangible and intangible) is known as resource management Malkawi (2018). Resource management entails planning so that the appropriate resources are assigned to the appropriate tasks. Schedules and budgets for people, projects, equipment, and supplies are all part of resource management. Each of the resource management aspects is discussed further below O'Bryan (2018).

Finances are managed to meet current expenses or investment in new equipment or staff training Vovchenko et al. (2017). When we talk of financial management, it mostly refers to planning, organising, directing, and controlling financial undertakings in an organisation or an institute. It may also be considered the use of management principles to the financial assets of an organisation and applying the rules of fiscal management Romano et al. (2018). When discussing 
financial management, these objectives are considered; maintaining enough funds for the organisation, ensuring shareholders of the organisation get good returns on their investment, Optimum and efficient utilisation of funds and creating real and safe investment opportunities to invest in. Management is an essential component of life and society. Everyone is involved in management at some level, whether they work alone, in a group, or simply manage their own time. People have formed groups since the beginning of recorded history to achieve goals that they could not achieve individually. This resulted in the natural evolution of fundamental managerial skills and principles in all social, economic, and ecological systems Nanda and Khare (2018). As a result, basic management principles and skills are required to lead an organization when and where people collaborate to achieve a common goal or vision. This also applies to the church. The different parts and contributions, as well as the allocated resources, must be managed effectively and efficiently within the unique framework of the church as an organization, metaphorically referred to as the body of Christ, in order for the organization to realize its intended goals and visions. The desire to manage the church is not new, but it is in high demand as a result of the rapidly changing global, social, political, and mobile environment Sovacool et al. (2020). The church must fight for its place in a market-driven economy while also ensuring its long-term viability. The point driven home is that managing the church as an organisation in line with sound management principles and practices cannot be ignored. Although it is commonly acknowledged that different churches and denominations deal with management in different ways, the universality of management skills and principles still apply to the church as an organisation in all its different forms and contexts.

Not a practical theological study, but a study in the management sciences with a church as a case study A management study with theological implications, in this sense. An interdisciplinary approach to church management is also possible, with a focus on management as an activity and the church as the object of that activity (theology).

Among other things, the church is unique as a faith-based organization because it has its own origin, its own message, its own purpose, its own ethic, its own reliance, and its own mission Collins and Clanton (2018). This means that the church must preserve its uniqueness as a faith-based organization in discussions and interactions with management science.

Aside from biblical principles relating to the church's structure, function, organization, and mission as a community of believers, the organization is also defined by the external environment, context, confessions, and traditions in which it exists Colby (2020). Despite the church's uniqueness as an organization, it has a lot in common with the structure, function, and organization of other organizations. Although some distinct characteristics differentiate the church from any other organisation, the church is still an organisation, sharing some common principles with other enterprises and therefore crying out to be managed effectively and efficiently. In supporting the argument that management science principles and skills apply to the church as an organisation, it will be important to trace the understanding and practice of management in the Bible and its specific reference to organised religious practice.

It should be noted that, in most situations, non-governmental organisations attract resources through non-commercial activities. Self-generating resources through commercial activity are less specific (but not excluded) for their organisational behaviour Mmaitsi (2020). As a community of believers, apart from the principles found in the Bible relating to structure, function, organization, and mission, the church is also defined by the external environment, context, 
confessions and traditions in which it stands Colby (2020). Despite the church's uniqueness as an organization, it has a lot in common with the structure, function, and organization of other organizations. The percentage of NGO revenues by the funding source is revenues from non-commercial activities and revenues from commercial activities. From this perspective, although they considered incomegenerating activities as being important, most NGOs lack both the skills and opportunities to achieve significant levels of funding by developing commercial activities.

Madurapperuma and Kim (2020) says NGOs may receive unconditional contribution/donation from the public and corporate bodies. A specific "unconditional contribution" case is payroll giving, known as "donation wage" or salary deduction. It means that an employee donates a preset part of his future wages with a certain frequency (most often monthly) for a certain period established by the act of donation to a charity.

Organisational resources are allocated and used in a way that can have a positive or negative impact on projects and overall company performance Pollok et al. (2019). Unfortunately, even companies with a lot of money can run out of resources and be unable to meet their customer's expectations. As a result of not being able to deliver, the company's reputation and brand can be negatively affected. It's common for service-based businesses to have a talent shortage, and these companies and their customers feel it the most when there's a shortage of talent in the workplace. When human talent is not allocated correctly within a service-based business, it can be far more devastating than in another type of business.

Creating a resource utilisation report can show you all the resources you have available and how they're currently performing Dimoff and Kelloway (2019). The fact that every project is unique makes it difficult to manage in a project management tool like Excel. Excel was once used by PMs to track resources, but it lacks the capabilities of more advanced tools for data projection and scenario analysis. Quality tools are needed to provide project managers with the agility and insight they require.

Dimoff and Kelloway (2019) claim that resource utilisation ultimately helps to make the most of the available resources. Because it prevents staff from underperforming or being overburdened by workloads and burning out, the proper use of resources is essential for maintaining productivity in this way, the risk of oversights can be reduced. Using resources to their maximum potential gives you a better ROI. It ensures that specific resources are not being over or under-utilised. It allows leaders to be agile and reschedule resources as quickly as possible to avoid problems surfacing or becoming worse.

Delery \& Roumpi (2017) present a conceptual model that suggests that HRM strategies are not simplistic tools. As most strategic human capital analysis postulates, companies can create a sustainable competitive advantage. On the other hand, they argue that HRM practices can contribute not only by developing staff skills and providing motivation and opportunities but also by shaping supply and demand-side movement constraints for the Company's sustainable competitive advantage.

Miller and Mehrotra (2015) analyse whether and when highly trained human capital is a valuable tool. Our study of 444 CEOs celebrated on the covers of major U.S. business magazines found an advantage accruing to graduates of selective universities. These CEOs have led companies that analyse the market more and more sustainably. The gain for undergraduate programs was greater as they related 
to a CEO's source of talent. The advantage was also highest in smaller companies with CEO flexibility and for younger CEOs who are most likely to enjoy college benefits and are less able to make reasonable rentals. Eventually, students in recent years earned the benefit of being less elitist and more meritocratic, preferring human- and social-capitalist selective schools.

Because they were investing in the training and development of their employees, they were getting better results. It is important for employees to know that there is a chance to grow, learn, and develop. Staff morale and organizational resources are enhanced by a commitment to professional development Lim et al. (2018). It is understandable for workers to have a perception that their career advancement opportunities are more important than to place them at a secured level in the workplace. That is to say that human capital is a major resource that every organisation dwells on for success. Losing the human capital base of an organisation means that the organisation spends time and money looking for a new employee before it can function effectively, connoting that the human capital has a direct link with the organisation's success.

Bartocho (2016) find employees to be the backbone of organisations as they ensure that company policies and programs are implemented effectively. Employee performance is linked with capital resource capabilities. Their study examined that human capital resource capabilities are a competitive tool in organisations for improved employee performance. The resources influenced by human capital were named to include physical resources, financial resources, and social resources. Their conclusion was made using a sample of 339 respondents was obtained using Cochran's formula. Simple random sampling was used and employed an explanatory research design. Data were analysed using descriptive and inferential statistics. Correlation and moderated regression analysis were used to test the hypotheses. The results revealed that physical capital resource capabilities had the most significant influence on employee performance, financial capital resource capabilities which also had a positive and statistically significant influence. Finally, the human capital resource capabilities, which this paper aimed to examine, had a positive relationship but statistically insignificant influence. Social capital resource capabilities were found not to be significantly associated with employee performance.

Junita (2016) finds an interactive relationship between the human resource system as an element of organisational capital and role behaviour as an element of human capital in strategic human resource management. Fugar et al. (2013), in a study, sought to identify the effect of human capital development on growth, profitability and competitive success. They find that investment in education has a positive correlation with organisational resources.

Lin et al. (2017) empirically tested the relationships among human capital management, employees' value and uniqueness, and organisational competitiveness. Their study uses a quantitative approach using multiple regression analysis on data gathered from 183 participants. Their results indicate that human capital development and deployment were positively associated with both value and uniqueness of employees. Training and job design were conducive to increasing employees' value and uniqueness.

Pasban and Nojedeh (2016) explore the associations between human capital resources, firm performance, and corporate governance mechanisms. As a result of their research, they determine that corporate governance mechanisms that support and enhance strategic human resource management policies have a positive impact on human resource performance. When interacting with human capital variables, 
some corporate governance mechanisms may have a negative effect on firm performance.

Nawaz (2019) conducted a study on 47 banks to determine the impact of investments in human capital on organisational resources. Their results reveal that human capital development correlates positively with organisational performance. Ma et al. (2019) conducted a study with 304 manufacturing firms across 13 economies and found that both task-related training and employee participation improve firm innovation in terms of the commercial success of new product development and the percentage of firm revenue from newly developed products.

Bontis et al. (2018) used empirical evidence to examine the relationship between human capital and firm performance. The findings indicate that human capital contributes to explain economic performance with evidence from valueadded per employee. Nonetheless, they observe that economic performance is negatively affected by the yearly training per employee.

Fareed et al. (2016) examine the correlation between high-performance work systems and organisational culture and human capital development. Furthermore, it also intends to test the moderating effect of organisational culture. The findings provide evidence of the association between human capital development and organisational culture with a high-performance work system. The research further finds a significant moderating effect of organisational culture on the relationship between high-performance work systems and human capital development.

\section{Conceptual Framework}

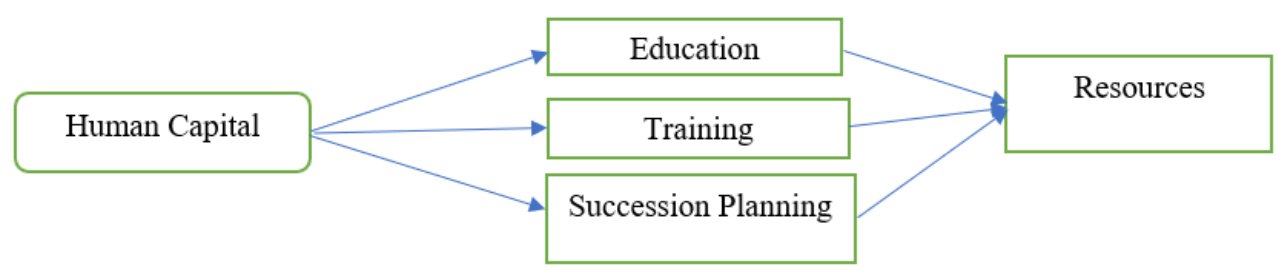

\section{Research Hypothesis}

H1: There is no significant relationship between human capital and resources.

H2: Human Capital does not predict resources.

\section{MATERIALS AND METHODS}

The study was carried out in a denominational institution in Ghana by gathering primary data through a questionnaire. The questionnaire was developed through a review of the literature. A sample size of 368 was used for the analysis of $99 \%$ confidence. A Likert scale ranging from one to four was used to measure the continuous variables of human capital and resources. A Minitab 20.3 software was used to generate the required results.

The researchers attempted to find out the relationship between the human capital and resources in selected denominational institutions in Ghana. Accordingly, the research hypothesis stated that there is no significant relationship between human capital and resources. The researchers implemented a reliability test in order to find out whether questions employed for human capital and resources were reliable or not. The reliability test analysed 22 questions for human capital and 15 
questions for resources. It was found that the Alpha for human capital $=.890$ and resources was 914 .

\begin{tabular}{|cccc}
\hline \multicolumn{4}{l}{ Table 1 Reliability Test } \\
\hline & Cronbach's Alpha & No. Items & Decision \\
\hline Human Capital & 0.890 & 22 & Acceptable \\
\hline Resources & 0.914 & 15 & Acceptable \\
\hline
\end{tabular}

\section{RESULTS AND DISCUSSIONS}

\section{Relationship}

By using the Pearson product-moment correlation coefficient, the analysis investigated the relationship between human capital and resources. To ensure that no breach of the assumptions of linearity, normality, and homoscedasticity was committed, initial analyses were conducted. Based on Cohen (1988) absolute correlation values, where $r=.10$ to .29 is small or low, $r=.30$ to .49 is medium or moderate, and $\mathrm{r}=.50$ to 1.0 is high or large, the strength of the relationship is calculated and interpreted. As shown in Error! Reference source not found., the relationship between human capital and resources revealed a high positive relationship between human capital and resources and was statistically significant $(\mathrm{r}=.503, \mathrm{p}=0.000)$. Therefore, the study rejects the null hypothesis that there is no significant relationship between human capital and resources. In a detail, scrutiny of the sub-variables for human capital and resources the results showed as follows: education relationship to resources was moderate positive statistically significant ( $\mathrm{r}$ $=0.491, \mathrm{p}=.000)$; training and resources was moderate positive statistically significant $(\mathrm{r}=-.405, \mathrm{p}=.000)$; succession planning low positive statistically significant $(\mathrm{r}=.220, \mathrm{p}=.000)$.

The analysis results show that human capital has a positive impact on the resources of the organisation; however, its occurrence is specific. The results imply that there is a positive relationship between human capital and resources in the denominational institution. This relationship has mainly resulted from the specific reasons of education, training and succession planning placement. They all showed a positive relationship as human capital becomes high, the better the resources been efficiently usage, accessibility and adequacy.

\begin{tabular}{|cccc|}
\hline Table 2 Correlations Analysis & Resources \\
\hline & \multicolumn{3}{c}{} \\
\hline & $\mathrm{R}$ & $\mathrm{Sig}$ & $\mathrm{VI}$ \\
\hline Education & $.491^{* *}$ & 0.000 & $\mathrm{~S}$ \\
\hline Training & $.405^{* *}$ & 0.000 & $\mathrm{~S}$ \\
\hline Succession Planning & $.220^{* *}$ & 0.000 & $\mathrm{~S}$ \\
\hline Human Capital & $.503^{* *}$ & 0.000 & $\mathrm{~S}$ \\
\hline
\end{tabular}

Source: Researchers Compilation

The outcome of this study is confirmed by Fu et al. (2020) investigated the impact of human capital on organisational innovation activities in the Chinese manufacturing industry. Furthermore, organisational innovation activities are 
classified into two categories: product innovation and process innovation. Using data from a World Bank survey of Chinese private manufacturing enterprises, the authors discover that executives' experience significantly affects process innovation. Growing the human capital base of an organisation is essential as it gives a resource pool in terms of skills and works potential for the organisation to rely on Ejemeyovwi et al. (2018). Human capital is considered the bedrock for organisational development due to its numerous effects on labour, capital, and other resources in organisations. Human capital possesses economic benefits since a knowledgeable workforce can increase productivity LeCounte et al. (2017).

\section{Regression Analysis}

The linear regression analysis approach was used to assess the ability of human capital as an independent variable to predict resources. As shown in Table 3, after going through the process, the total variance explained by the model as a whole is $\mathbf{3 1 . 2 6 \%}, \mathbf{F}=55.17, \mathrm{p}<.000$. However, there are $68.74 \%$ variables, which were not considered in this study but can explain resources in Ghana's denominational institutions. The proposed applied model based on the unstandardized beta for this study is Resources $=0.927+0.3814$ education +0.1912 training + 0.0762 succession planning $+\boldsymbol{\varepsilon}$. As a result, the study rejects the null hypothesis that none of the human capital predictors of resources. The result implies that resources can be accounted for improvement based on positive human capital and high human capital, the better usage of resources of the denominational institution.

\begin{tabular}{|c|c|c|c|c|c|}
\hline \multicolumn{6}{|l|}{ Table 3 Prediction of Resources } \\
\hline Term & Coef & SE Coef & T-Value & P-Value & VIF \\
\hline Constant & 0.927 & 0.161 & 5.78 & 0.000 & \\
\hline education & 0.3814 & 0.0451 & 8.45 & 0.000 & 1.17 \\
\hline training & 0.1912 & 0.0424 & 4.51 & 0.000 & 1.25 \\
\hline \multirow{2}{*}{ succession planning placement } & 0.0762 & 0.0267 & 2.85 & 0.005 & 1.08 \\
\hline & $\mathrm{R}^{2}=31.26 \%$ & $F=55.17$ & & & \\
\hline
\end{tabular}

\section{CONCLUSIONS AND RECOMMENDATIONS}

The findings of the empirical analysis demonstrate that there is a significant and positive relationship between human capital and resources. The predictor of resources, as revealed by this study, were education, training and succession planning. From the predictive results, the explained variable on resources was $31.26 \%$. Human capital must be improved, and this can be achieved by supporting educational advancement, training the workers on the job, and instituting an appraisal system to take care of succession planning placement. It is recommended that future researchers should look for other variables, which were not used in this study to predict resources such as Church members commitments.

\section{REFERENCES}

Amiri, A.N., Jandaghi, G., \& Ramezan, M. (2011). An Investigation to the Impact of Intellectual Capital on Organizational Innovation. European Journal of Scientific Research 64 (3), 472-477. 
Baker, B. L., \& Blacher, J. (2020). Brief report: Behavior disorders and social skills in adolescents with autism spectrum disorder: Does IQ matter?. Journal of autism and developmental disorders, 50(6), 2226-2233. Retrieved from https://doi.org/10.1007/s10803-019-03954-w

Barro, R. J. (2001). Human capital and growth. American economic review, 91(2), 12-17. Retrieved from https://doi.org/10.1257/aer.91.2.12

Bartocho, E. (2016). Utilization of Human Capital Resource Capabilities As a. Global Journal of Human Resource Management, 4(2), 21-29.

Blaug, M. (1976). The empirical status of human capital theory: A slightly jaundiced survey. Journal of economic literature, 14(3), 827-855. Retrieved from https://www.jstor.org/stable/2722630

Bontis, N., Ciambotti, M., Palazzi, F., \& Sgro, F. (2018). Intellectual capital and financial performance in social cooperative enterprises. Journal of Intellectual Capital, 19(4), 712-731. Retrieved from https://doi.org/10.1108/JIC-03-2017-0049

Brel, Y. (2018). NGOs in Romania: An Assessment of Their Impact on Strengthening Civil Society and Promoting Democracy in Cluj-Napoca, Romania. Retrieved from https://udspace.udel.edu/handle/19716/27907

Chan, K. M., Boyd, D. R., Gould, R. K., Jetzkowitz, J., Liu, J., Muraca, B., ... \& Brondízio, E. S. (2020). Levers and leverage points for pathways to sustainability. People and Nature, 2(3), 693-717. Retrieved from https://doi.org/10.1002/pan3.10124

Chhetri, P., Gekara, V., Manzoni, A., \& Montague, A. (2018). Productivity benefits of employer-sponsored training: A study of the Australia transport and logistics industry. Education+ Training. Retrieved from https://doi.org/10.1108/ET-02-2017-0029

Ciccone, A., \& Papaioannou, E. (2009). Human capital, the structure of production, and growth. The review of economics and statistics, 91(1), 66-82. Retrieved from https://doi.org/10.1162/rest.91.1.66

Colby, B. (2020). Evaluating the Role of Empowering Leadership and Church Health (Doctoral dissertation, Southeastern University).

Collins, C. S., \& Clanton, J. C. (2018). On the distinctive function of Christian higher education and the common good. Christian Higher Education, 17(1-2), 8-19. Retrieved from https://doi.org/10.1080/15363759.2018.1404359

Delery, J. E., \& Roumpi, D. (2017). Strategic human resource management, human capital and competitive advantage: is the field going in circles?. Human Resource Management Journal, 27(1), 1-21. Retrieved from https://doi.org/10.1111/1748-8583.12137

Dimoff, J. K., \& Kelloway, E. K. (2019). With a little help from my boss: The impact of workplace mental health training on leader behaviors and employee resource utilization. Journal of occupational health psychology, 24(1), 4. Retrieved from https://doi.org/10.1037/ocp0000126

Ejemeyovwi, J. O., Osabuohien, E. S., \& Osabohien, R. (2018). ICT investments, human capital development and institutions in ECOWAS. International Journal of Economics and Business Research, 15(4), 463-474. Retrieved from https://doi.org/10.1504/IJEBR.2018.10012862

Estrin, S., Mickiewicz, T., \& Stephan, U. (2016). Human capital in social and commercial entrepreneurship. Journal of Business Venturing, 31(4), 449467. Retrieved from https://doi.org/10.1016/j.jbusvent.2016.05.003 
Fareed, M., Noor, W. S. W. M., Isa, M. F. M., \& Salleh, S. S. M. M. (2016). Developing human capital for sustainable competitive advantage: The roles of organizational culture and high performance work system. International Journal of Economic Perspectives, 10(4), 655-673. Retrieved from

https://www.researchgate.net/profile/Muhammad-Fareed-

12/publication/319304634_Developing_human_capital_for_sustainable_co mpetitive_advantage_The_roles_of_organizational_culture_and_high_perfor mance_work_system/links/59e85d8ba6fdccfe7f8b4787/Developinghuman-capital-for-sustainable-competitive-advantage-The-roles-oforganizational-culture-and-high-performance-work-system.pdf

Francis, I. (2020). Succession planning and asset optimization of manufacturing firms in south east Nigeria. International Journal of Advanced Research in Management and Social Sciences, 9(10), 14-44. Retrieved from

https://www.indianjournals.com/ijor.aspx?target=ijor:ijarmss\&volume=9\&issue= 10\&article $=001$

Fries, A., Kammerlander, N., \& Leitterstorf, M. (2020). Leadership styles and leadership behaviors in family firms: A systematic literature review. Journal of Family Business Strategy, 100374. Retrieved from https://doi.org/10.1016/j.jfbs.2020.100374

Fugar, F. D. ., Ashiboe-Mensah, N. ., \& Adinyira, E. (2013). Human Capital Theory: Implications for the. Journal of Construction Project Management and Innovation, 3(1), 464-479.

Gray, C. M. (2019). Using profiles of human and social capital to understand adult immigrants' education needs: A latent class approach. Adult Education Quarterly, 69(1), 3-23. Retrieved from https://doi.org/10.1177/0741713618802271

Junita, A. (2016). The Interaction between Human and Organizational Capital in Strategic Human Resource Management. International Research Journal of Business Studies, 9(1), 49-62. Retrieved from https://doi.org/10.21632/irjbs.9.1.49-62

Kandade, K., Samara, G., Parada, M. J., \& Dawson, A. (2021). From family successors to successful business leaders: A qualitative study of how high-quality relationships develop in family businesses. Journal of Family Business Strategy, 12(2), $100334 . \quad$ Retrieved from https://doi.org/10.1016/j.jfbs.2019.100334

Kotur B. R. \& Anbazhagan (2014). Education and Work-Attitude - Influence on the Performance. Journal of Business and Management, 16(5), 104-110. Retrieved from https://doi.org/10.9790/487X-1653104110

Kuzminov, Y., Sorokin, P., \& Froumin, I. (2019). Generic and specific skills as components of human capital: New challenges for education theory and practice. Форсайт, 13(2 (eng)). Retrieved from https://doi.org/10.17323/2500-2597.2019.2.19.41

Kyenzi, E. K., Kinyili, J., \& Nzioki, S. (2020). Human Resource Practices Influencing Employees Productivity in the Department of National Registration Bureau Nairobi County, Kenya. Retrieved from https://doi.org/10.24940/theijbm/2020/v8/i9/BM2009-041

LeCounte, J., Prieto, L., \& Phipps, S. T. (2017). CEO Succession Planning and Organizational Performance: A Human Capital Theory Approach. Journal of Leadership, Accountability, and Ethics, 14(1), 46-57. Retrieved from http://www.na-businesspress.com/JLAE/LeCounte_abstract.html 
Lim, S. S., Updike, R. L., Kaldjian, A. S., Barber, R. M., Cowling, K., York, H., ... \& Leever, A. T. (2018). Measuring human capital: a systematic analysis of 195 countries and territories, 1990-2016. The Lancet, 392(10154), 1217-1234. Retrieved from https://doi.org/10.1016/S0140-6736(18)31941-X

Lin, C., Wang, C. Y. P., Wang, C. Y., \& Jaw, B. S. (2017). The role of human capital management in organizational competitiveness. Social Behavior and Personality, 45(1), 81-92. Retrieved from https://doi.org/10.2224/sbp.5614

Madurapperuma, M. A. Y. D., \& Kim, K. M. (2020). Sustaining Business: A Psychological Perspective of Donation Behavior. Sustainability, 12(22), 9355. Retrieved from https://doi.org/10.3390/su12229355

Malkawi, N. (2018). using electronic human resource management for organizational excellence-case study at social security corporation-Jordan. International Journal of Engineering Technologies and Management Research, 5(5), 146-166. $\quad$ Retrieved from https://doi.org/10.29121/ijetmr.v5.i5.2018.237

Miller, D., Xu, X., \& Mehrotra, V. (2015). When is human capital a valuable resource? The performance effects of Ivy League selection among celebrated CEOs. Strategic Management Journal, 36(6), 930-944. Retrieved from https://doi.org/10.1002/smj.2251

Mmaitsi, L. A. (2020). ASSESSING CHALLENGES AND OPPORTUNITIES IN RESOURCE MOBILIZATION AND FUNDRAISING FOR NONGOVERNMENTAL ORGANIZATIONS IN NAROK TOWN, KENYA. European Journal of Social Sciences Studies, 5(6). Retrieved from http://dx.doi.org/10.46827/ejsss.v5i6.931

Nanda, G., \& Khare, A. (2018). Spatial Mapping of 'People-Place Ties' as an Integral Part of Heritage Management Process. Journal of Heritage Management, 3(2), 192-208. Retrieved from https://doi.org/10.1177/2455929618807984

Nawaz, T. (2019). Exploring the Nexus Between Human Capital, Corporate Governance and Performance: Evidence from Islamic Banks. Journal of Business Ethics, 157(2), 567-587. Retrieved from https://doi.org/10.1007/s10551-017-3694-0

O'Bryan, K. (2018). Indigenous rights and water resource management: Not just another stakeholder. Routledge. Retrieved from https://doi.org/10.4324/9781351239820

Ocen, E., Francis, K., \& Angundaru, G. (2017). The role of training in building employee commitment: the mediating effect of job satisfaction. European Journal of Training and Development. Retrieved from https://doi.org/10.1108/EJTD-11-2016-0084

Pasban, M., \& Nojedeh, S. H. (2016). A Review of the Role of Human Capital in the Organization. Procedia - Social and Behavioral Sciences, 230(May), 249-253. Retrieved from https://doi.org/10.1016/j.sbspro.2016.09.032

Pfeifer, H., \& Backes-Gellner, U. (2018). Another piece of the puzzle: Firms' investment in training as production of optimal skills inventory. Empirical Research in Vocational Education and Training, 10(1), 1-17. Retrieved from https://doi.org/10.1186/s40461-018-0067-6

Pollok, P., Lüttgens, D., \& Piller, F. T. (2019). How firms develop capabilities for crowdsourcing to increase open innovation performance: The interplay between organizational roles and knowledge processes. Journal of Product 


$\begin{array}{lllll}\text { Innovation Management, 36(4), 412-441. } & \text { Retrieved } & \text { from } \\ \text { https://doi.org/10.1111/jpim.12485 } & & & \end{array}$

Renshaw, I., Davids, K., Araújo, D., Lucas, A., Roberts, W. M., Newcombe, D. J., \& Franks, B. (2019). Evaluating weaknesses of "perceptual-cognitive training" and "brain training" methods in sport: An ecological dynamics critique. Frontiers in psychology, 9, 2468. Retrieved from https://doi.org/10.3389/fpsyg.2018.02468

Robinson, J. (2017). Next generation leadership: The changing culture of leadership in the senior student affairs officer (SSAO) position. College Student Affairs Journal, 35(2), 70-84. $\quad$ Retrieved from https://doi.org/10.1353/csj.2017.0014

Romano, M., Nicotra, M., Armando, P., \& Castello, E. (2018). Financial management of publicly funded research activities: an explorative study. International Journal of Managerial and Financial Accounting, 10(1), 1-15. Retrieved from https://doi.org/10.1504/IJMFA.2018.10011746

Roy, S., Morton, M., \& Bhattacharya, S. (2018). Hidden human capital: Self-efficacy, aspirations and achievements of adolescent and young women in India. World Development, 111, 161-180. Retrieved from https://doi.org/10.1016/j.worlddev.2018.07.002

Sima, V., Gheorghe, I. G., Subić, J., \& Nancu, D. (2020). Influences of the industry 4.0 revolution on the human capital development and consumer behavior: A systematic review. Sustainability, 12(10), 4035. Retrieved from https://doi.org/10.3390/su12104035

Sovacool, B. K., Del Rio, D. F., \& Griffiths, S. (2020). Contextualizing the Covid-19 pandemic for a carbon-constrained world: Insights for sustainability transitions, energy justice, and research methodology. Energy Research \& Social Science, 68, 101701. Retrieved from https://doi.org/10.1016/j.erss.2020.101701

Szmelter-Jarosz, A., Rześny-Cieplińska, J., \& Jezierski, A. (2020). Assessing resources management for sharing economy in urban logistics. Resources, 9(9), 113. Retrieved from https://doi.org/10.3390/resources9090113

Teixeira, A. A., \& Tavares-Lehmann, A. T. (2014). Human capital intensity in technology-based firms located in Portugal: Does foreign ownership matter?. Research Policy, 43(4), 737-748. Retrieved from https://doi.org/10.1016/j.respol.2014.01.001

Tse, H. H., To, M. L., \& Chiu, W. C. (2018). When and why does transformational leadership influence employee creativity? The roles of personal control and creative personality. Human Resource Management, 57(1), 145-157. Retrieved from https://doi.org/10.1002/hrm.21855

Van Raaij, W. F. (2016). The Use of Natural Resources. Handbook of Economic Psychology, 638-655. Retrieved from https://doi.org/10.1007/978-94015-7791-5_18

Vovchenko, N. G., Holina, M. G., Orobinskiy, A. S., \& Sichev, R. (2017). Ensuring financial stability of companies on the basis of international experience in construction of risks maps, internal control and audit. Retrieved from https://doi.org/10.35808/ersj/623

Wright, P. M., \& Ulrich, M. D. (2017). A road well traveled: The past, present, and future journey of strategic human resource management. Annual Review of Organizational Psychology and Organizational Behavior, 4, 45-65. Retrieved from https://doi.org/10.1146/annurev-orgpsych-032516-113052 
Does Human Capital Predict Resources: Evidence from Denominational Institutions in Ghana?

Zaidi, S. A. H., Wei, Z., Gedikli, A., Zafar, M. W., Hou, F., \& Iftikhar, Y. (2019). The impact of globalization, natural resources abundance, and human capital on financial development: Evidence from thirty-one OECD countries. Resources Policy, 64, $101476 . \quad$ Retrieved from https://doi.org/10.1016/j.resourpol.2019.101476 